\title{
Phylogeny of Prosthecobacter, the Fusiform Caulobacters: Members of a Recently Discovered Division of the Bacteria
}

\author{
BRIAN P. HEDLUND, * JOHN J. GOSINK, AND JAMES T. STALEY \\ Department of Microbiology, University of Washington, Seattle, Washington 98195-7242
}

\begin{abstract}
Prosthecobacter fusiformis is morphologically similar to caulobacters; however, it lacks a dimorphic life cycle. To determine the relatedness of the genus Prosthecobacter to dimorphic caulobacters and other prosthecate members of the $\alpha$ subgroup of the Proteobacteria ( $\alpha$-Proteobacteria), we isolated and sequenced 16S rRNA genes from four Prosthecobacter strains. Surprisingly, the results of phylogenetic analyses placed the fusiform caulobacters in a deeply rooted division of the Bacteria that was most closely affiliated with the PlanctomycesChlamydia group and only distantly related to the $\alpha$-Proteobacteria. The genus Prosthecobacter shares a common lineage in this division with Verrucomicrobium spinosum, a polyprosthecate, heterotrophic bacterium. Consistent with this phylogenetic placement, menaquinones were isolated from Prosthecobacter strains and menaquinones have been isolated from Verrucomicrobium strains and planctomycetes but not from members of the $\alpha$-Proteobacteria. Thus, the genus Prosthecobacter is a second genus in the recently described order Verrucomicrobiales. Members of the genus Prosthecobacter are susceptible to $\beta$-lactam antibiotics and contain mesodiaminopimelic acid, indicating that they, unlike members of the Planctomycetales or Chlamydiales, have peptidoglycan cell walls. This major phenotypic difference, together with the phylogenetic independence of the verrucomicrobia, indicates that these bacteria and the sources of related $16 \mathrm{~S}$ ribosomal DNAs obtained from soils, freshwater, and the marine pelagic environment represent an unrecognized division of the Bacteria.
\end{abstract}

Prosthecae are narrow extensions of the cell wall that contain cytoplasm (49). The most widely known prosthecate bacteria are the caulobacters. Collectively, the caulobacters were defined as rod-shaped or vibrioid heterotrophs that possess single, polar, unbranched prosthecae and divide by transverse fission (19). Prototypical caulobacters have a dimorphic life cycle (53). Each cell divides asymmetrically, producing a nonprosthecate, motile swarmer cell and a sessile, prosthecate cell; the swarmer cell develops a prostheca, there is a concomitant loss of motility, and the cell subsequently divides. These bacteria are placed in the genera Caulobacter and Asticcacaulis on the basis of whether the cells have polar or subpolar prosthecae $(34,36)$.

In contrast, a caulobacter that Henrici and Johnson called the fusiform caulobacter divides symmetrically, and each resulting cell possesses a prostheca at the time of division (19). Furthermore, neither cell is motile. The cells of this caulobacter remain attached at the divisional pole following fission; thus, the daughter cells form mirror images of one another.

Whereas dimorphic caulobacters were isolated as early as 1905 (21) and 1914 (33), pure cultures of the fusiform caulobacter were not obtained until the 1970s. The following four strains were isolated: FC1 (= ATCC 27091), FC2, FC3, and $\mathrm{FC}^{\mathrm{T}}{ }^{\mathrm{T}}\left(=\mathrm{ATCC} 25309^{\mathrm{T}}\right)(\mathrm{T}=$ type strain) $(8,51)$. Although all of these organisms are freshwater isolates, they were isolated from geographically distant regions of the United States and from both oligotrophic (strain $\mathrm{FC4}^{\mathrm{T}}$ ) and eutrophic (strain FC1) environments. Other attempts to isolate fusiform caulobacters from enrichment cultures with media containing plant extracts (62), from Antarctic sea ice (30), or from other freshwater sources (38) have failed, perhaps because of the complex nutritional requirements of these bacteria.

\footnotetext{
* Corresponding author. Mailing address: Department of Microbiology, University of Washington, Box 357242, Seattle, WA 98195-7242. Phone: (206) 543-6646. Fax: (206) 543-8297. Electronic mail address: brianh@u.washington.edu.
}

Nonetheless, pure-culture studies performed with the four fusiform caulobacter strains led to greater understanding of the differences between these organisms and the dimorphic caulobacters. In addition to the obvious developmental differences, morphological, nutritional, and genetic differences were identified $(29,51)$; together, the differences were striking enough to place the fusiform caulobacters in a separate genus, the genus Prosthecobacter, which contains a single described species, Prosthecobacter fusiformis (type strain, FC4) (51).

Phylogenetically, the dimorphic caulobacters, the genera Caulobacter and Asticcacaulis, belong to the alpha subdivision of the Proteobacteria $(\alpha-$ Proteobacteria) $(46,48)$. These organisms share a common lineage in this division with other heterotrophic prosthecate bacteria, including the genera Hyphomicrobium, Pedomicrobium, Filomicrobium, Hyphomonas (46), Prosthecomicrobium, Ancalomicrobium (43), Stella (13), and Hirschia (42). The phylogenetic position of the fusiform caulobacters has never been determined (50). To assess whether the genus Prosthecobacter is related to prosthecate members of the $\alpha$-Proteobacteria, we determined the phylogenetic positions of all four Prosthecobacter strains by performing a $16 \mathrm{~S}$ ribosomal DNA (rDNA) sequence analysis. We supplemented the results of the phylogenetic analysis with data from comparisons of chemotaxonomic markers which have been used to classify prosthecate bacteria (45).

\section{MATERIALS AND METHODS}

Electron microscopy. Cells were shadowed with platinum-palladium and were viewed with a model JEM-100B electron microscope operated at $60 \mathrm{kV}$.

$16 S$ rDNA sequencing and phylogenetic analysis. Prior to the phylogenetic analysis, Prosthecobacter $16 \mathrm{~S}$ rDNA was purified and sequenced. Genomic DNA was isolated from late-exponential-phase cells by using an InstaGene kit (BioRad, Hercules, Calif.). 16S rDNA was amplified by PCR by using universal primers (39) and the following parameters: 32 cycles consisting of $1.5 \mathrm{~min}$ at $94^{\circ} \mathrm{C}, 1 \mathrm{~min}$ at $42^{\circ} \mathrm{C}$, and $4 \mathrm{~min}$ at $72^{\circ} \mathrm{C}$, with the last step of the last cycle continuing for $10 \mathrm{~min}$ (16). For strains FC1 and FC3, the PCR product was digested with Not $\mathrm{I}$, isolated by agarose gel electrophoresis, and purified by using a Prep-A-Gene kit (Bio-Rad). The purified product was cloned into pBluescript II $\mathrm{KS}^{+}$(Stratagene, La Jolla, Calif.) by using standard techniques (40). Multiple clones were pooled and sequenced together by using a Taq DyeDeoxy terminator 
TABLE 1. 16S rDNA sequences and nucleotide positions used in this study

\begin{tabular}{|c|c|c|c|}
\hline Organism or clone & $\begin{array}{c}\text { GenBank } \\
\text { accession no. }\end{array}$ & Division $^{\alpha}$ & $\begin{array}{l}\text { Nucleotide } \\
\text { positions }^{b}\end{array}$ \\
\hline Thermotoga maritima MSB8 (= DSM 3109) & M21774 & 2.2, Thermotogales & $27-1491$ \\
\hline Chloroflexus aurantia J-10-F1 (= ATCC 29366) & M34116 & 2.4 , Green nonsulfur bacteria & $27-1483$ \\
\hline Cytophaga flevensis ATCC 27944 & M58767 & 2.6, Flexibacter-Cytophaga-Bacteroides & $27-1490$ \\
\hline Chlorobium vibrioforme 6030 (= DSM 260) & M62791, M27804 & 2.7, Green sulfur bacteria & $27-1491$ \\
\hline Pirellula staleyi ATCC $27277^{\mathrm{T}}$ & M34126 & 2.9.1, Planctomyces-Planctomyces & $27-1491$ \\
\hline Chlamydia psittaci 6BC (= ATCC VR125) & M13769 & 2.9.2, Planctomyces-Chlamydia & $27-1491$ \\
\hline Vernucomicrobium spinosum IFAM 1439 & X90515 & 2.9.3, Planctomyces-Verrucomicrobium & $31-1481$ \\
\hline Clone env.MC15 & X64382 & 2.9.3, Planctomyces-Verrucomicrobium & $27-996,1224-1223$ \\
\hline Clone env.MC17 & $\mathrm{X} 64381$ & 2.9.3, Planctomyces-Verrucomicrobium & $27-996,1224-1223$ \\
\hline Clone env.MC18 & X64374 & 2.9.3, Planctomyces-Verrucomicrobium & $27-1240$ \\
\hline Clone env.MC31 & $\mathrm{X} 64380$ & 2.9.3, Planctomyces-Verrucomicrobium & $70-996,1224-1223$ \\
\hline Nostoc muscorum & $\mathrm{X} 59559$ & 2.10, Cyanobacteria plus chloroplasts & $27-1491$ \\
\hline Fibrobacter succinogenes A3C (= ATCC 51219) & M62683 & 2.11, Fibrobacter phylum & $27-1377$ \\
\hline Spirochaeta halophila $\mathrm{RS1}^{\mathrm{T}}\left(=\right.$ ATCC $\left.29478^{\mathrm{T}}\right)$ & M88722, M34262 & 2.12 , Spirochetes and their relatives & $27-1377$ \\
\hline Caulobacter crescentus $\mathrm{CB} 2 \mathrm{~A}$ & M83799 & 2.13.1, Purple bacteria, $\alpha$-Proteobacteria & 27-1479 \\
\hline Caulobacter subvibrioides CB81 & M83797 & 2.13.1, Purple bacteria, $\alpha$-Proteobacteria & $27-1481$ \\
\hline Neisseria gonorrhoeae B5025 $\left(=\right.$ ATCC $\left.19424^{\mathrm{T}}\right)$ & X07714 & 2.13.2, Purple bacteria, $\beta$-Proteobacteria & $27-1491$ \\
\hline Escherichia coli & J01695 & 2.13.3, Purple bacteria, $\gamma$-Proteobacteria & $27-1491$ \\
\hline Desulfovibrio desulfuricans ATCC 27774 & M34113 & 2.13.4, Purple bacteria, $\delta$-Proteobacteria & $27-1491$ \\
\hline Fusobacterium gonidoformans ATCC 25563 & M58679 & 2.14, Fusobacteria and their relatives & $27-1489$ \\
\hline Streptomyces lividans TK21 & Y00484 & 2.15.1, Gram positive high $\mathrm{G}+\mathrm{C}$ content & $27-1491$ \\
\hline Clostridium pasteurianum ATCC 6013 & M23930 & 2.15.2, Gram positive low $\mathrm{G}+\mathrm{C}$ content & $27-1489$ \\
\hline
\end{tabular}

\footnotetext{
${ }^{a}$ Divisions as described in Ribosomal Database Project version 5.0 (23).

${ }^{b}$ Nucleotide positions corresponding to the positions on the E. coli $16 \mathrm{~S}$ rRNA gene (4). The following nucleotide positions were deleted because nucleotide alignment was uncertain: E. coli positions 69 to 101,163 to 169,182 to 226,433 to 504,838 to 853 , and 997 to 1044 (4).
}

cycle sequencing kit (Applied Biosystems, Foster City, Calif.) and 16S rDNAspecific forward and reverse primers $(10)$.

The PCR products of FC2 and $\mathrm{FC} 4{ }^{\mathrm{T}}$ were purified by using a Prep-A-Gene kit and were sequenced directly. As a result of the fact that multiple 16S rDNA copies from each organism were sequenced, interoperon sequence variations, if they existed, were reported as ambiguous nucleotides or as the nucleotides that clearly predominated among copies of the gene (5).

Because of a sequence discrepancy between Prosthecobacter 16S rRNA genes and sequencing primers, the following three additional primers were required to complete the sequence analysis: SP3Rprosth (GGCTGCTGCCTCCCGTAGG; Escherichia coli positions 357 to 341 [4]), SP7Rgamma (TACCGGGGTATCTA ATCC; $E$. coli positions 802 to 785 [4]), and SP13Rgamma (ACGGGCGGTG TGTACAA; E. coli positions 1406 to 1390 [4]).

16S rDNA sequences were assembled by using the SeqApp program (15) and were initially aligned with similar sequences by using the Ribosomal Database Project version 5.0 ALIGN SEQUENCE program (23). Additional sequences used in the phylogenetic analyses were obtained from the Ribosomal Database Project (23) or from GenBank (Table 1). Manual adjustments of the aligned data set were made. In addition, Prosthecobacter sequences were projected onto the Pirellula staleyi 16S rRNA secondary-structure model (17) to check for correct alignment of homologous nucleotides and to allow for comparisons of secondarystructure motifs. Since the data set included sequences from taxa belonging to many divisions of the Bacteria, certain regions of the 16S rRNA gene could not be confidently aligned. As comparisons of nucleotides which are not evolutionary counterparts can misguide phylogenetic analyses (32), we deleted these nucleotides (E. coli positions 69 to 101,163 to 169,182 to 226,433 to 504,838 to 853 , and 997 to 1044 [4]) from all of the sequences, as has been done by other workers (3).

The single data set without nucleotides whose alignment was uncertain was analyzed by using several phylogenetic methods. Maximum-likelihood and parsimony analyses were performed by using fastDNAml $(11,31)$ and PAUP3.0 (54), respectively. The programs used in the neighbor-joining analysis were obtained from the PHYLIP package, version 3.2 (12).

Quinone analysis. Two-liter batch cultures of Prosthecobacter sp. strains FC1 and $\mathrm{FC4}^{\mathrm{T}}$ were grown with rapid shaking on $\mathrm{MMB}$, a dilute peptone-yeast extract medium amended with glucose (52). As Prosthecobacter strains do not require exogenously added vitamins, the vitamin solution was omitted. Cells were harvested during the late exponential phase of growth and lyophilized. The lyophilized cells were extracted, and ubiquinone and menaquinone fractions were purified by thin-layer chromatography (6). The quinone bands were scraped from the plate, eluted with chloroform, dried under $\mathrm{N}_{2}$, and stored at $4^{\circ} \mathrm{C}$ in the dark until they were analyzed.

Final separation and identification of individual ubiquinones and menaquinones were performed by reverse-phase high-performance liquid chromatography with a Waters model 510 pump as described previously (6). The following bacteria whose quinone compositions have been published previously (7) were treated in parallel and were used as standards: Rhodococcus erythropolis ATCC 4277, E. coli, and Pseudomonas putida ATCC 29607. To identify the Prosthecobacter menaquinone, the numbers of isoprene units in standard menaquinone homologs were plotted against the logarithm of the net retention time (quinone retention time - solvent peak retention time) to form a straight line (7). This line was extrapolated from MK- $8\left(\mathrm{H}_{2}\right)$ and MK- $7\left(\mathrm{H}_{2}\right)$ of $R$. erythropolis through MK$6\left(\mathrm{H}_{2}\right)$ of Prosthecobacter strains.

meso-Diaminopimelic acid isolation. Prosthecobacter strains and $R$. erythropolis and $E$. coli reference strains were grown and harvested. Cells were hydrolyzed with $6 \mathrm{~N} \mathrm{HCl}$ by autoclaving them for $15 \mathrm{~min}$ as described previously (18). Hydrolysates were spotted onto Sigma type 100 cellulose thin-layer chromatography plates along with LL-, DD-, and meso-diaminopimelic acid standards (Sigma Chemical Co., St. Louis, Mo.), and the plates were developed (18). Diamino acids were visualized with ninhydrin reagent.

Determination of antibiotic MICs. Antibiotic MICs were determined as follows: $1 \times 10^{7}$ to $3 \times 10^{7}$ late-exponential-phase cells of Prosthecobacter sp. strain FC1 or FC2 were added to defined media (51) containing serial dilutions of penicillin $\mathrm{G}$ or ampicillin in microtiter wells, and growth was scored by measuring the increase in turbidity at $600 \mathrm{~nm}$ with a model EL311sx automated microplate reader (BIO-TEK, Winooski, Vt.) and a Delta Soft II apparatus (BioMetallics, Princeton, N.J.) after incubation for 3 or 5 days at room temperature. The MIC 


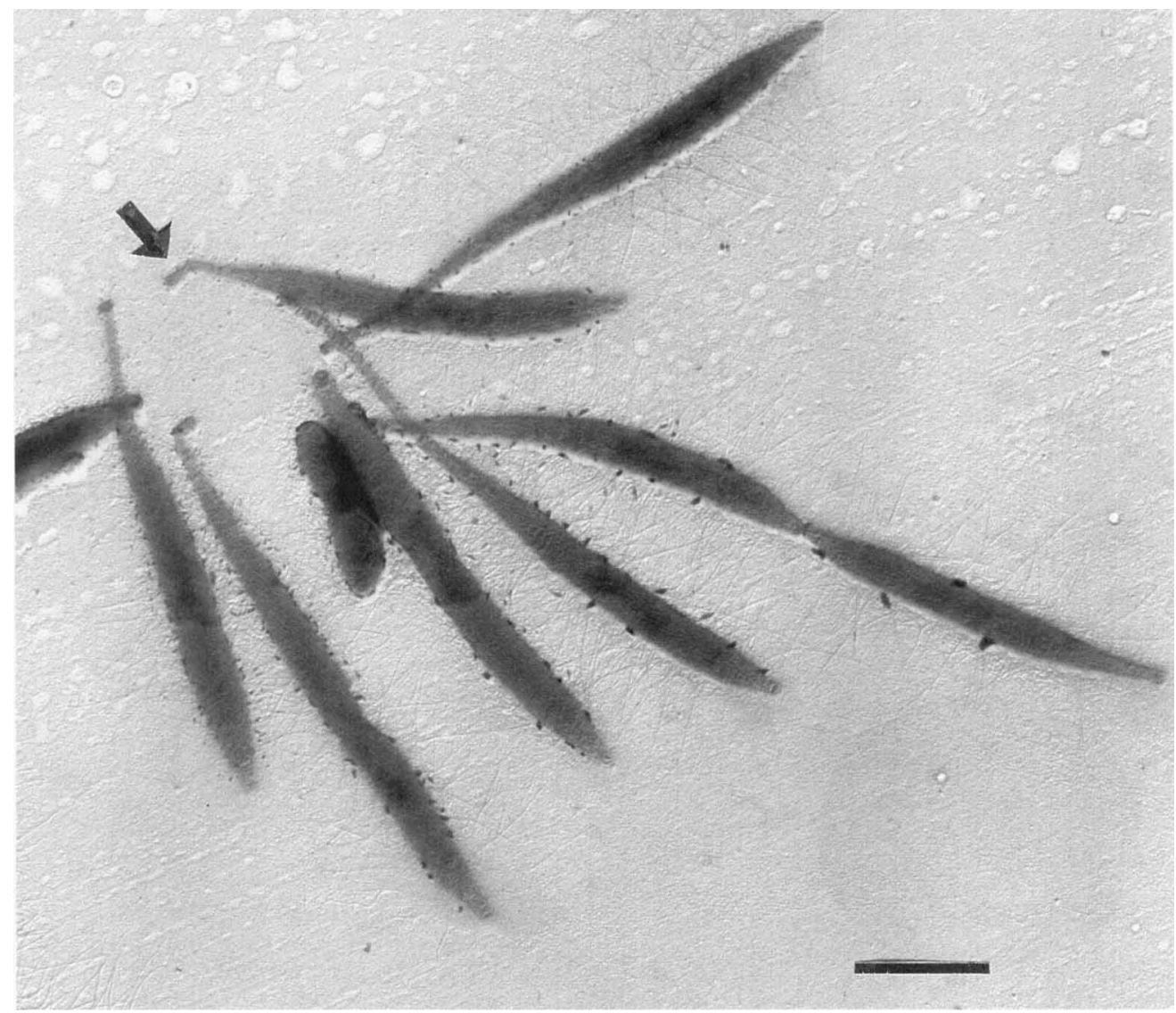

FIG. 1. Shadowed electron micrograph of Prosthecobacter sp. strain FC2. Note the numerous radiating fimbriae and the distinctive bulbs at the prostheca tips (arrow). Bar $=2 \mu \mathrm{m}$.

was defined as the lowest antibiotic concentration which completely prevented growth.

Nucleotide sequence accession numbers. The 16S rDNA sequences of Prosthecobacter sp. strains $\mathrm{FC} 1, \mathrm{FC} 2, \mathrm{FC} 3$, and $\mathrm{FC}^{\mathrm{T}}$ have been deposited in the GenBank database under accession numbers U60012, U60013, U60014, and U60015, respectively.

\section{RESULTS}

Electron microscopy. An electron micrograph of Prosthecobacter sp. strain FC2 (Fig. 1) shows that the cells of this organism are heavily fimbriate; this feature is absent from prosthecate dimorphic caulobacter surfaces (34). In addition, Prosthecobacter prosthecae have bulbous tips which are unique among bacteria. A close examination of Prosthecobacter prosthecae failed to reveal cross bands, which are characteristic of Caulobacter appendages $(34,36,37)$.

Phylogenetics. The sequences of the four Prosthecobacter $16 \mathrm{~S}$ rDNAs were determined and compared with each other and with the most closely related sequences obtained from the Ribosomal Database Project (Table 2). The 16S rDNA sequences of the Prosthecobacter strains exhibited higher levels of homology with each other than with any other sequence, indicating that the genus Prosthecobacter is a phylogenetically coherent group. When ambiguous nucleotides were excluded, the levels of $16 \mathrm{~S}$ rDNA sequence similarity among the prosthecobacters ranged from 98.3 to $94.8 \%$. Generally, $16 \mathrm{~S}$ rDNA sequence divergence values between 1 and $2 \%$ correspond to $50 \%$ DNA-DNA hybridization $(2,9,47,48)$; correspondingly, organisms that exhibit less than $70 \%$ DNA-DNA hybridization qualify as separate species (59). Thus, the levels of 16S rDNA sequence difference between Prosthecobacter strains are at or above the level which separates bacterial species. This is consistent with the results of DNA-DNA hybridization experiments performed with strain $\mathrm{FC}^{\mathrm{T}}$ and the other Prosthecobacter strains; the levels of DNA-DNA hybridization between strain $\mathrm{FC}^{\mathrm{T}}$ and strains $\mathrm{FC} 1, \mathrm{FC} 2$, and $\mathrm{FC} 3$ were 5,1 , and $3 \%$, respectively (29).

The Prosthecobacter sequences exhibited high levels of homology ( 89.8 to $90.2 \%$ ) with the $16 \mathrm{~S}$ rDNA sequence of only one cultured bacterium, Verrucomicrobium spinosum $(1,58)$. V. spinosum is a polyprosthecate, heterotrophic bacterium that was isolated from a eutrophic, alkaline lake in Germany (41). Phylogenetically, $V$. spinosum is separate from the $\alpha$-Proteobacteria (1). Thus, the genus Prosthecobacter belongs to the recently described order Verrucomicrobiales (58) and is not closely related to the dimorphic caulobacters, with which it was previously associated (19). This result is surprising considering the gross morphological similarity between Prosthecobacter strains and Caulobacter strains and since this is only the second example of a heterotrophic, prosthecate organism outside the well-defined cluster of prosthecate bacteria within the $\alpha$-Proteobacteria.

As determined by levels of sequence similarity, the genus Prosthecobacter is also linked to 16 S rDNA clones representing uncultured bacteria obtained from several environments. These clones include clones obtained from a paddy field (env.PAD7, env.PAD18, and env.PAD50) (55), a clone obtained from a soybean field (env.FIE19) (55), a clone obtained from 
TABLE 2. Levels of 16S rDNA homology between Prosthecobacter sequences and sequences of organisms representing main lines of descent within the Bacteria ${ }^{a}$

\begin{tabular}{|c|c|c|c|c|}
\hline \multirow[t]{2}{*}{ Organism } & \multicolumn{4}{|c|}{$\begin{array}{l}\% \text { Homology with the following } \\
\text { Prosthecobacter strains: }\end{array}$} \\
\hline & $\mathrm{FC} 1$ & $\mathrm{FC} 2$ & FC3 & $\mathrm{FC} 4^{\mathrm{T}}$ \\
\hline Chlorobium vibrioforme & 78.9 & 78.3 & 78.5 & 78.9 \\
\hline Nostoc muscorum & 78.8 & 78.1 & 78.0 & 78.5 \\
\hline Fusobacterium gonidoformans & 76.7 & 76.3 & 76.5 & 75.9 \\
\hline Streptomyces lividans & 80.6 & 81.1 & 80.8 & 80.5 \\
\hline Clostridium pasteuri & 80.7 & 80.0 & 80.4 & 80.5 \\
\hline Cytophaga flevens & 76.2 & 76.0 & 76.0 & 76.1 \\
\hline Caulobacter crescentus & 79.8 & 79.5 & 79.2 & 79.6 \\
\hline Neisseria gonorrhoeae ATCC $19424^{\mathrm{T}}$ & 78.6 & 78.5 & 77.9 & 78.4 \\
\hline Escherichia coli & 79.1 & 79.0 & 78.9 & 78.8 \\
\hline Desulfovibrio desulfuricans & 81.9 & 81.5 & 81.0 & 81.5 \\
\hline Fibrobacter succinogenes & 77.3 & 77.2 & 77.6 & 77.4 \\
\hline Spirochaeta halophila ATCC $29478^{\mathrm{T}}$ & 77.5 & 77.5 & 77.0 & 77.2 \\
\hline Thermotoga maritima & 77.3 & 77.5 & 76.8 & 77.1 \\
\hline Chloroflexus aurantia & 76.7 & 77.0 & 75.9 & 76.5 \\
\hline Pirellula staleyi ATCC $27277^{\mathrm{T}}$ & 75.1 & 75.3 & 74.9 & 74.9 \\
\hline Chlamydia psittaci & 78.8 & 78.4 & 78.6 & 78.6 \\
\hline
\end{tabular}

${ }^{a}$ The nucleotide positions used in the analysis are shown in Table 1.

soil (EA25) (24), cluster III MC clones obtained from Australian forest soil (env.MC15, env.MC17, env.MC18, and env.MC31) (25), clones obtained from Adirondack lakes (AckM6, Ack-M10, Ack-DE36, Ack-DE41, Ack-DH1, and AckDH7) (20), clones obtained from a Carolina bay (RB35, RB31, RB02, RB24, RB14, RB01, and RB22) (60), and a clone obtained from a depth of $100 \mathrm{~m}$ in the Atlantic Ocean (env.25-19) (14). Therefore, relatives of the genus Prosthecobacter are prevalent in the environment even though they (probably) have not been cultured. Unfortunately, many sequences representing uncultured bacteria consisted of less than $25 \%$ of the $16 \mathrm{~S}$ rRNA gene; therefore, it was not possible to determine the precise phylogenetic relationships between the genus Prosthecobacter and the bacteria from which the rDNA clones were obtained.

We compared the Prosthecobacter sequences with the $16 \mathrm{~S}$ rDNA sequences of several representatives of each of the major bacterial phyla (61). The resulting levels of homology were between 68.2 and $76.1 \%$, values which were at or below the values that separate members of different divisions (data not shown). To demonstrate that these values were not artifactual because of poor sequence alignment, we repeated this analysis with a data set from which positions of uncertain alignment were excluded. Still, the levels of homology were as low as the levels of homology between members of different divisions. Thus, on the basis of distance alone, the position of the Prosthecobacter-Verrucomicrobium group within the existing bacterial divisions is uncertain. Representative data are shown in Table 2.

To substantiate the phylogenetic relationship between the genus Prosthecobacter and V. spinosum and the cluster III MC clones, we searched for signature nucleotides which have been reported to be unique to the sequences of these organisms $(25$, 58 ). Indeed, three of four nucleotide signatures (at $E$. coli positions 768 [G], 811 [A], and 819 [G] [4]) of the $V$. spinosum and cluster III MC clone sequences were found in all four Prosthecobacter strains. The fourth nucleotide signature (at $E$. coli positions 826 and 874 [U - A]) was found in FC2; however, the other Prosthecobacter strains had the more common base pair, $\mathrm{C} \cdot \mathrm{G}$. This analysis also revealed the presence of four Planctomyces nucleotide signatures (at E. coli positions 47 and $394[\mathrm{G} \cdot \mathrm{G}], 48[\mathrm{~A}], 53$ and $539[\mathrm{G} \cdot \mathrm{C}]$, and 955 [C] [61]), each of which is also present in the $V$. spinosum and cluster III $\mathrm{MC}$ clone sequences $(25,58)$. The presence of these nucleotide signatures supports the placement of the Prosthecobacter group in the Planctomyces-Chlamydia supergroup. The majority of the Planctomycetales signatures, however, are not present in Prosthecobacter strains, which reflects the independence of the genus Prosthecobacter from the Planctomyces phylum. Interestingly, on the basis of sequence homology data alone, the prosthecobacters are only distantly related to the planctomycetes (Table 2).

Phylogenetic trees were created to determine relationships within and around the Prosthecobacter-Verrucomicrobium radiation. All of the trees were constructed by using data sets restricted to nucleotides whose alignment was certain. A data set consisting of Prosthecobacter, V. spinosum, and cluster III $\mathrm{MC}$ clone $16 \mathrm{~S}$ rDNA sequences along with sequences representing some of the major bacterial phyla was analyzed to find the most parsimonious trees (54). The resulting four trees, which had equal total branch lengths, were analyzed by using MacClade 3.05 (27). The four trees had an average transitionto-transversion ratio of 1.05 .

The results of a maximum-likelihood analysis $(11,31)$ of the data set with the transition-to-transversion ratio adjusted to 1.05 confirmed the phylogenetic coherence of the prosthecobacters and of the Prosthecobacter- $V$. spinosum-cluster III MC clone cluster (Fig. 2). The maximum-likelihood tree also suggested that the Prosthecobacter group diverged at an early point from a common ancestor of the genera Planctomyces and

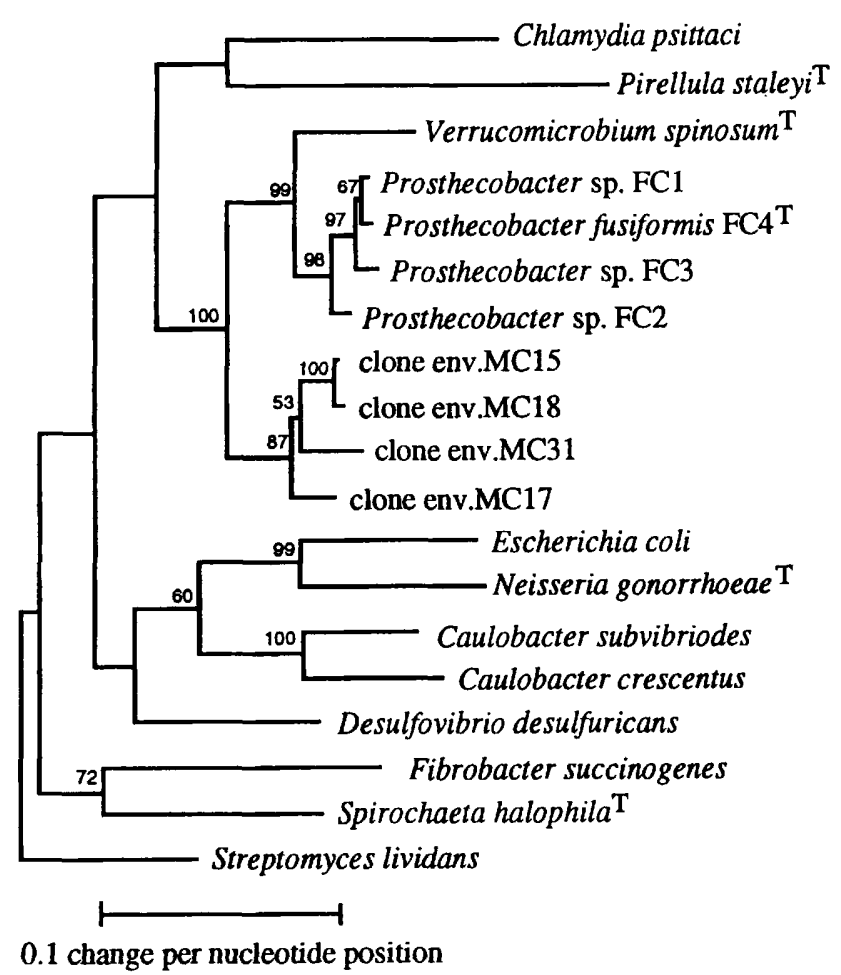

FIG. 2. Maximum-likelihood $(11,31)$ analysis of $16 \mathrm{~S}$ rDNA sequences from Prosthecobacter strains, Verrucomicrobium strains, and cluster III MC environmental clones, as well as bacteria representing established phyla. The numbers above the nodes are bootstrap values (based on 100 resamplings). Only bootstrap values greater than $50 \%$ are shown. Scale bar $=0.1$ average change per nucleotide position. The nucleotide positions used in the analysis are shown in Table 1. 


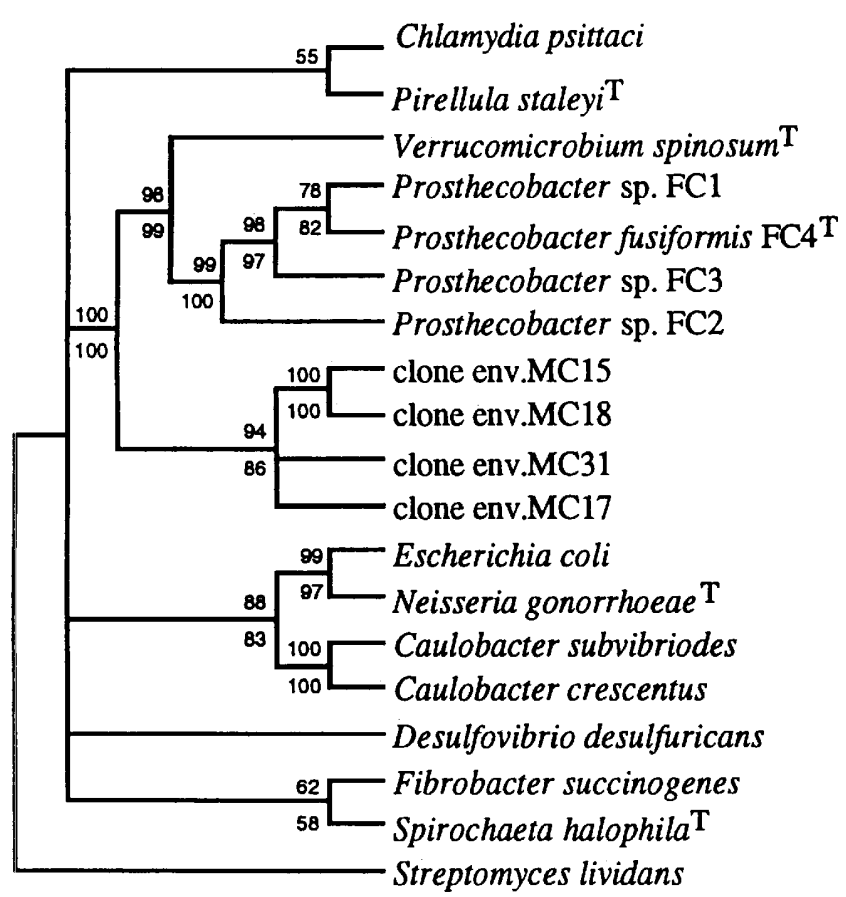

FIG. 3. Cladogram showing the results of bootstrap parsimony analyses. Heuristic searches were conducted by using PAUP3.0s (47) with a random input order and 10 replications per bootstrap. The numbers above the nodes are bootstrap percentages (based on 100 resamplings) obtained by the unweighted parsimony method. The numbers below the nodes are bootstrap percentages obtained from an identical analysis in which only transversions were counted. Only bootstrap values greater than $50 \%$ are shown. The nucleotide positions used in the analyses are shown in Table 1.

Chlamydia. However, support from 100 bootstrap resamplings failed to favor any particular relationship between the major divisions of the Bacteria. In particular, there was less than $50 \%$ support for a specific relationship between the Prosthecobacter group and the Planctomyces or Chlamydia group.

The same data set was analyzed by DNADIST (12), using a Kimura two-parameter correction, a random input order, and a transition-to-transversion ratio of 1.05 . When analyzed by NEIGHBOR (12), the resulting distance matrix produced a tree whose topology was similar to that of the maximum-likelihood tree (Fig. 2); the only difference was the relative positions of env.MC17 and env.MC31 (data not shown). Again, however, the bootstrap values supporting the early divergence of the Prosthecobacter group from the Planctomyces-Chlamydia lineage were less than $50 \%$.

Finally, the unweighted data set was analyzed by using PAUP3.0s (54). A heuristic search with 10 different random input orders (54) produced a tree similar to the trees created by the other methods (Fig. 3). Again, however, the same method and 100 bootstrap resamplings failed to associate Prosthecobacter and related sequences with any established division. Importantly, a low, but significant bootstrap value supported grouping the planctomycetes and chlamydiae without the genus Prosthecobacter. This finding supports the hypothesis that the verrucomicrobia diverged from the Planctomyces-Chlamydia superphylum at an early point. An identical analysis in which only transversions were weighted yielded a similar tree with similar bootstrap values (Fig. 3).

Peptidoglycan analysis. We isolated $m$-diaminopimelic acid from Prosthecobacter extracts. In addition, Prosthecobacter strains were susceptible to penicillin G (MIC, $10 \mu \mathrm{g} / \mathrm{ml}$ ) and ampicillin (MIC, $0.3 \mu \mathrm{g} / \mathrm{ml}$ ). Taken together, these data indicate that the members of the genus Prosthecobacter have peptidoglycan cell walls. Since all known members of the Planctomyces and Chlamydia phyla lack peptidoglycan cell walls (22), the presence of peptidoglycan in the genus Prosthecobacter supports a phylogenetic branching scheme in which the genus Prosthecobacter diverged before the genera Planctomyces and Chlamydia diverged.

Quinone analysis. Quinone profiles have recently been used to group prosthecate bacteria (45). Although ubiquinones are the predominant quinones in aerobically cultivated prosthecate members of the Proteobacteria, menaquinones are found in Verrucomicrobium strains. We isolated both menaquinones and ubiquinones from aerobically grown prosthecobacters. However, menaquinone MK- $6\left(\mathrm{H}_{2}\right)$ was the predominant quinone in extracts of both $\mathrm{FCl}$ and $\mathrm{FC}_{4}^{\mathrm{T}}$, providing further evidence that the genera Prosthecobacter and Verrucomicrobium are related (Table 3 ). Interestingly, menaquinone MK-6 $\left(\mathrm{H}_{2}\right)$ is also the dominant respiratory quinone in planctomycetes (45); this supports the hypothesis that the genus Prosthecobacter is more closely related to the planctomycetes and chlamydiae than to the members of the Proteobacteria.

\section{DISCUSSION}

Prosthecae greatly increase the surface area of cells, and thus it has been proposed that these structures confer several advantages to aerobic heterotrophic bacteria. These advantages include enhanced respiration and nutrient uptake (44),

TABLE 3. Phenotypic characteristics of representatives of two phylogenetically distinct groups of heterotrophic prosthecate bacteria

\begin{tabular}{|c|c|c|c|c|c|c|c|c|c|c|c|}
\hline \multirow[b]{2}{*}{ Genus } & \multicolumn{2}{|c|}{ Prosthecae } & \multirow{2}{*}{$\begin{array}{c}\mathrm{G}+\mathrm{C} \text { content } \\
\text { of DNA } \\
(\mathrm{mol} \%)\end{array}$} & \multirow[b]{2}{*}{ Fimbriae } & \multirow[b]{2}{*}{ Motility } & \multirow[b]{2}{*}{$\begin{array}{l}\text { Fermen- } \\
\text { tative }\end{array}$} & \multicolumn{4}{|c|}{ Utilization of: } & \multirow[b]{2}{*}{$\begin{array}{c}\text { Major } \\
\text { quinone(s) }\end{array}$} \\
\hline & Distribution & No./cell & & & & & $\begin{array}{l}\text { Carbo- } \\
\text { hydrates }\end{array}$ & $\begin{array}{l}\text { Amino } \\
\text { acids }\end{array}$ & $\begin{array}{l}\text { Other } \\
\text { organic } \\
\text { acids }\end{array}$ & $\begin{array}{l}\text { Primary } \\
\text { alcohols }\end{array}$ & \\
\hline \multicolumn{12}{|l|}{ Verrucomicrobiales group } \\
\hline Prosthecobacter ${ }^{a}$ & Polar & 1 & $54.6-60.1$ & $+^{b}$ & - & - & + & - & - & - & MK-6(H 2$)$, Q-n \\
\hline $\begin{array}{c}\text { Verrucomicrobium }{ }^{c} \\
\alpha \text {-Proteobacteria group }\end{array}$ & Radiating & $5-30$ & $57.9-59.3$ & + & - & + & + & - & - & - & MK-10, MK-6 \\
\hline Caulobacter & Polar & 1 & $62-67$ & $\mathrm{D}$ & + & - & + & + & $\mathrm{D}$ & - & Q-10 \\
\hline Prosthecomicrobium $^{e}$ & Radiating & $10-30$ & $65-70$ & - & $\mathrm{D}$ & - & $\mathrm{D}$ & + & $\mathrm{D}$ & + & Q-10 \\
\hline
\end{tabular}

${ }^{a}$ Data from reference 51 and this study.

${ }^{b}+, 90 \%$ or more of the strains are positive; D, 10 to $90 \%$ of the strains are positive;,$- 10 \%$ or fewer of the strains are positive.

${ }^{c}$ Data from references 41 and 45 .

${ }^{d}$ Data from references 37 and 45 .

${ }^{\mathcal{c}}$ Data from references 45 and 50 
as well as decreased sedimentation in aquatic environments $(35,53)$. In addition, holdfasts on the tips of some prosthecae allow bacteria to attach to solid substrates in favorable local environments (28). All things considered, it is not surprising that examples of heterotrophic prosthecate bacteria are found in more than one major division of the Bacteria.

All heterotrophic prosthecate bacteria that have been isolated and thoroughly characterized to date belong to one of two phylogenetically distinct groups, the Verrucomicrobiales and the $\alpha$-Proteobacteria. Members of these two groups are similar in many ways; however, there appear to be three distinct phenotypic traits of members of the genus Prosthecobacter that are found only in members of the Verrucomicrobiales (Table 3). First, both Verrucomicrobium strains and Prosthecobacter strains are heavily fimbriate $(41,51)$, whereas no heavily fimbriate, prosthecate members of the $\alpha$-Proteobacteria have been isolated in pure culture. Second, the verrucomicrobia contain menaquinones rather than ubiquinones as their predominant respiratory quinones (45). Third, the known members of the Verrucomicrobiales utilize only a narrow range of carbohydrates as sole sources of carbon $(41,51)$; some members of the $\alpha$-Proteobacteria utilize a much wider range of substrates $(37,50)$. These criteria should prove to be useful in classifying prosthecate heterotrophic bacteria in the future.

It has been proposed previously that the order Verrucomicrobiales and related $16 \mathrm{~S}$ rDNA clones represent a unique division of the Bacteria $(1,25,58)$. We support this proposal on the basis of genetic data as well as phenotypic data. Phylogenetically, members of the Verrucomicrobiales are excluded from the planctomyces and chlamydia divisions by the three criteria used by Woese and his collaborators (61) to define the phyla of the Bacteria (in this study we regard the phyla defined by Woese [61] as divisions). First, as determined by a by distance analysis, the members of the genera Prosthecobacter and Verrucomicrobium (1) exhibit equally low levels of $16 \mathrm{~S}$ rDNA homology with representatives of each of the established divisions of the Bacteria (61). Second, although Verrucomicrobium sequences contain four planctomyces nucleotide signatures, the majority of the signatures used to define the planctomyces phylum are absent. Too few Chlamydia sequences exist to define the signatures of this group. Third, the predicted secondary-structure features of Verrucomicrobium 16S rRNA molecules do not closely resemble Planctomycetales or Chlamydia features (data not shown). For example, Prosthecobacter 16S rRNAs contain a short helix at E. coli positions 184 to 193 (4) and a long helix at E. coli positions 198 to 219 (4). Both of these higher-order structures are rare among bacteria and occur together only in the $\beta$ - and $\gamma$-Proteobacteria and not in the planctomyces or the chlamydiae $(17,61)$. Therefore, in the absence of a more rigorous definition for a bacterial division, the Verrucomicrobiales must be considered a novel division of the Bacteria.

Correspondingly, although the Verrucomicrobiales seems to be associated with the planctomycetes and chlamydiae, each of three phylogenetic methods used failed to place the verrucomicrobia in any previously described division of the Bacteria. Instead, the genus Prosthecobacter, $V$. spinosum, and related clones formed an isolated, robust clade that was supported by $100 \%$ of the bootstrap values in each phylogenetic analysis. Of particular significance was the fact that the unweighted parsimony method excluded the verrucomicrobia from the planctomyces-chlamydia group, implying that the branch point for the verrucomicrobia was deep. However, the exact verrucomicrobium-planctomycetes-chlamydia branching order should not be accepted as fact since the results obtained with other phylogenetic methods failed to support any particular order with strong bootstrap values and since the order of division level divergence is, in general, uncertain $(26,56)$. Finally, since the lack of peptidoglycan is a defining characteristic of both the planctomyces and the chlamydiae, the presence of peptidoglycan cell walls in members of the Verrucomicrobiales strongly supports the proposal that these bacteria are separate from the planctomyces and chlamydiae (61).

The fact that large taxonomic units like the verrucomicrobium division are still being added to the Bacteria is a testament to the vast microbial diversity yet to be discovered. Indeed, microbial diversity is still an exciting frontier in biology. To date, the division which contains the Verrucomicrobiales consists of only two genera of freshwater bacteria; however, molecular ecology studies have revealed that these bacteria are ubiquitous. Thus, the majority of the diversity within and around the Verrucomicrobiales remains totally uncharacterized. If the correct culturing approach is taken, a better understanding of the diversity within this group can be attained, as has recently been done for the Planctomycetales (57).

\section{ACKNOWLEDGMENTS}

We thank Matthew A. Stoecker for assistance with quinone identification and $m$-diaminopimelic acid isolation and for a critical evaluation of the manuscript. In addition, we thank Robert Bigford for taking electron micrographs. We are also indebted to Allen G. Rodrigo for productive input concerning phylogenetic analyses. We thank Allison D. Geiselbrecht for editing comments. Finally, we thank William D. Hiorns and Mark G. Wise for discussions concerning unpublished data.

\section{REFERENCES}

1. Albrecht, W., A. Fischer, J. Smida, and E. Stackebrandt. 1987. Verrucomicrobium spinosum, a eubacterium representing an ancient line of descent. Syst. Appl. Microbiol. 10:57-62.

2. Amann, R. I., C. Lin, R. Key, L. Montgomery, and D. A. Stahl. 1992. Diversity among Fibrobacter isolates: towards a phylogenetic classification. Syst. Appl. Microbiol. 15:23-31.

3. Andrésson, O., and O. Fridjónsson. 1994. The sequence of the single $16 \mathrm{~S}$ rRNA gene of the thermophilic eubacterium Rhodothermus marinus reveals a distant relationship to the group containing Flexibacter, Bacteroides, and Cytophaga species. J. Bacteriol. 176:6165-6169.

4. Brosius, J., M. L. Palmer, P. J. Kennedy, and H. F. Noller. 1978. Complete nucleotide sequence of a $16 \mathrm{~S}$ ribosomal RNA gene from Escherichia coli. Proc. Natl. Acad. Sci. USA 75:4801-4805.

5. Clayton, R. A., G. Sutton, J. P. S. Hinkle, C. Bult, and C. Fields. 1995. Intraspecific variation in small-subunit rRNA sequences in GenBank: why single sequences may not adequately represent prokaryotic taxa. Int. J. Syst. Bacteriol. 45:595-599.

6. Collins, M. D. 1985. Analysis of isoprenoid quinones, p. 329-365. In G. Gottschalk (ed.), Methods in microbiology. Academic Press, Orlando, Fla.

7. Collins, M. D., and D. Jones. 1981. Distribution of isoprenoid quinone structural types in bacteria and their taxonomic implications. Microbiol, Rev. 45:316-354.

8. DeBont, J. A. M., J. T. Staley, and H. S. Pankratz. 1970. Isolation and description of a non-motile, fusiform, stalked bacterium, a representative of a new genus. Antonie van Leeuwenhoek 36:397-407.

9. Devereux, R., S. He, C. L. Doyle, S. Orkland, D. A. Stahl, J. LeGall, and W. B. Whitman. 1990. Diversity and origin of Desulfovibrio species: phylogenetic definition of a family. J. Bacteriol. 172:3609-3619.

10. Dyksterhouse, S. E., J. P. Gray, R. P. Herwig, J. C. Lara, and J. T. Staley. 1995. Cycloclasticus pugetti gen. nov., sp. nov., an aromatic hydrocarbondegrading bacterium from marine sediments. Int. J. Syst. Bacteriol. 45:116123.

11. Felsenstein, J. 1981. Evolutionary trees from DNA sequences: a maximum likelihood approach. J. Mol. Evol. 17:368-376.

12. Felsenstein, J. 1989. PHYLIP-phylogeny inference package (version 3.2). Cladistics 5:164-166.

13. Fischer, A., T. Roggentin, H. Shlesner, and E. Stackebrandt. 1985. 16S rRNA oligonucleotide cataloguing and the phylogenetic placement of Stella humosa. Syst. Appl. Microbiol. 6:43-47.

14. Fuhrman, J. A., K. McCallum, and A. A. Davis. 1993. Phylogenetic diversity of subsurface marine microbial communities from the Atlantic and Pacific Oceans. Appl. Environ. Microbiol. 59:1294-1302.

15. Gilbert, D. G. 1992. SeqApp 1.9a169, a biological sequence editor and analysis for Macintosh computers. Published electronically on the Internet 
and available via anonymous file transfer ftp to ftp.bio.indiana.edu.

16. Gosink, J. J., and J. T. Staley. 1995. Biodiversity of gas vacuolate bacteria from Antarctic sea ice and water. Appl. Environ. Microbiol. 61:3486-3489

17. Gutell, R. R. 1993. Collection of small subunit (16S- and 16S-like) ribosomal RNA structures. Nucleic Acids Res. 21:3051-3054.

18. Haswega, T., M. Takizawa, and S. Tanida. 1983. A rapid analysis for chemical grouping of aerobic actinomycetes. J. Gen. Appl. Microbiol. 29:319-322.

19. Henrici, A. T., and D. E. Johnson. 1935. Studies of freshwater bacteria. II Stalked bacteria, a new order of Schizomycetes. J. Bacteriol. 30:61-93.

20. Hiorns, W. D., B. A. Menthé, and J. P. Zehr. 1996. Bacterial communities in diverse Adirondack lakes described by $16 \mathrm{~S}$ rRNA gene sequences, abstr. N122. In Abstracts of the 96th General Meeting of the American Society for Microbiology 1996. American Society for Microbiology, Washington, D.C.

21. Jones, M. 1905. A peculiar microorganism showing rosette formation. Zentralbl. Bakteriol. Parasitenkd. Infectionskr. Hyg. Abt. 2 14:459-463.

22. Koenig, W., H. Schlesner, and P. Hirsch. 1984. Cell wall studies on budding bacteria of the planctomyces-pasteuria group and on a Prosthecomicrobium sp. Arch. Microbiol. 138:200-205.

23. Larsen, N., G. J. Olsen, B. L. Maidak, M. J. McCaughey, R. Overbeek, T. J Macke, T. L. Marsh, and C. R. Woese. 1993. The Ribosomal Database Project. Nucleic Acids Res. 21:3021-3023.

24. Lee, S. Y., J. Bollinger, D. Bedicek, and A. Ogram. 1996. Unpublished data

25. Liesack, W., and E. Stackebrandt. 1992. Occurrence of novel groups of the domain Bacteria as revealed by analysis of genetic material isolated from an Australian terrestrial environment. J. Bacteriol. 174:5072-5078.

26. Liesack, W., R. Söeller, T. Stewart, H. Haas, S. Giovannoni, and E. Stackebrandt. 1992. The influence of tachytelically (rapidly) evolving sequences on the topology of phylogenetic trees - intrafamily relationships and the phylogenetic position of Planctomycetaceae as revealed by comparative analysis of 16 S ribosomal RNA sequences. Syst. Appl. Microbiol. 15:357-362.

27. Maddison, W. P., and D. R. Maddison. 1992. MacClade: analysis of phylogeny and character evolution, version 3.0. Sinauer Associates, Sunderland, Mass.

28. Merker, R. I., and J. Smit. 1988. Characterization of the adhesive holdfast of marine and freshwater caulobacters. Appl. Environ. Microbiol. 54:20782085.

29. Moore, R. L., J. Schmidt, J. Poindexter, and J. T. Staley. 1978. Deoxyribonucleic acid homology among the caulobacters. Int. J. Syst. Bacteriol. 28 349-353.

30. Nam, C., and J. T. Staley. Unpublished data.

31. Olsen, G. J., H. Matsuda, R. Hagstrom, and R. Overbeek. 1994. fastDNAml: a tool for construction of phylogenetic trees of DNA sequences using maximum likelihood. Comput. Appl. Biosci. 10:41-43.

32. Olsen, G. J., and C. R. Woese. 1993. Ribosomal RNA: a key to phylogeny. FASEB J. 7:113-123.

33. Omeliansky, V. L. 1914. A new bacillus: Bacillus flagellatus. Zh. Mikrobiol Epidemiol. Immunobiol. 1:24

34. Poindexter, J. S. 1964. Biological properties and classification of the Cau lobacter group. Bacteriol. Rev. 28:231-295.

35. Poindexter, J. S. 1978. Selection for nonbuoyant morphological mutants of Caulobacter crescentus. J. Bacteriol. 135:1141-1145

36. Poindexter, J. S. 1981. The caulobacters: ubiquitous unusual bacteria. Microbiol. Rev. 45:123-179.

37. Poindexter, J. S. 1992. Dimorphic prosthecate bacteria: the genera Caulobacter, Asticcacaulis, Hyphomicrobium, Pedomicrobium, Hyphomonas, and Thiodendron, p. 2176-2196. In A. Balows, H. G. Trüper, M. Dworkin, W. Harder, and K. H. Schleifer (ed.), The prokaryotes, 2nd ed. Springer-Verlag, New York.

38. Poindexter, J. S. Personal communication.

39. Reysenbach, A.-L., G. S. Wickham, and N. R. Pace. 1994. Phylogenetic analysis of the hyperthermophilic pink filament community in Octopus Spring, Yellowstone National Park. Appl. Environ. Microbiol. 60:2113-2119.

40. Sambrook, J., E. F. Fritsch, and T. Maniatis. 1989. Molecular cloning: laboratory manual, 2nd. ed. Cold Spring Harbor Laboratory Press, Cold Spring Harbor, N.Y.
41. Schlesner, H. 1987. Verucomicrobium spinosum gen. nov., sp. nov.: a fimbriated prosthecate bacterium. Syst. Appl. Microbiol. 10:54-56.

42. Schlesner, H., C. Bartels, M. Sittig, M. Dorsch, and E. Stackebrandt. 1990 Taxonomic and phylogenetic studies on a new taxon of budding hyphal proteobacteria, Hirschia baltica gen. nov., sp. nov. Int. J. Syst. Bacteriol. 40:443-451.

43. Schlesner, H., T. Kath, A. Fischer, and E. Stackebrandt. 1989. Studies on the phylogenetic position of Prosthecomicrobium pneumaticum, P. enhydrum, Ancalomicrobium adetum, and various Prosthecomicrobium-like bacteria. Syst. Appl. Microbiol. 12:150-155.

44. Schmidt, J. 1971. Prosthecate bacteria. Annu. Rev. Microbiol. 25:93-110.

45. Sittig, M., and H. Schlesner. 1993. Chemotaxonomic investigation of various prosthecate and/or budding bacteria. Syst. Appl. Microbiol. 16:92-103.

46. Stackebrandt, E., A. Fischer, T. Roggentin, U. Wehmeyer, D. Bomar, and J. Smida. 1988. A phylogenetic survey of budding, and/or prosthecate, nonphototrophic eubacteria: membership of Hyphomicrobium, Hyphomonas, Pedomicrobium, Filomicrobium, Caulobacter, and "Dichotomicrobium" to the alpha-subdivision of purple non-sulfur bacteria. Arch. Microbiol. 149:547556.

47. Stackebrandt, E., and B. M. Goebel. 1994. Taxonomic note: a place for DNA-DNA reassociation and $16 \mathrm{~S}$ rRNA sequence analysis in the present species definition in bacteriology. Int. J. Syst. Bacteriol. 44:846-849.

48. Stahl, D. A., R. Key, B. Flesher, and J. Smit. 1992. The phylogeny of marine and freshwater caulobacters reflects their habitat. J. Bacteriol. 174:21932198.

49. Staley, J. T. 1968. Prosthesomicrobium and Ancalomicrobium: new freshwater prosthecate bacteria. J. Bacteriol. 95:1921-1942.

50. Staley, J. T. 1992. The genera Prosthecomicrobium, Ancalomicrobium, and Prosthecobacter, p. 2160-2164. In A. Balows, H. G. Trüper, M. Dworkin, W Harder, and K. H. Schleifer (ed.), The prokaryotes, 2nd ed. Springer-Verlag, New York.

51. Staley, J. T., J. A. M. DeBont, and K. DeJonge. 1976. Prosthecobacter fusiformis nov. gen. et sp., the fusiform caulobacter. Antonie van Leeuwenhoek 42:333-342.

52. Staley, J. T., and M. Mandel. 1973. Deoxyribonucleic acid base composition of Prosthecomicrobium and Ancalomicrobium strains. Int. J. Syst. Bacteriol. 23:271-273.

53. Stove, J. L., and R. Y. Stainier. 1962. Cellular differentiation in stalked bacteria. Nature (London) 196:1189-1192.

54. Swofford, D. L. 1991. PAUP: phylogenetic analysis using parsimony. Illinois Natural History Survey, Champaign.

55. Ueda, T., Y. Suga, and T. Matsuguchi. 1995. Molecular phylogenetic analysis of a soil microbial community in a soybean field. Eur. J. Soil Sci. 46:415-421.

56. Van de Peer, Y., J. Neefs, P. DeRijk, P. DeVos, and R. DeWachter. 1994. About the order of divergence of the major bacterial taxa during evolution. Syst. Appl. Microbiol. 17:32-38.

57. Ward, N., F. A. Rainey, E. Stackebrandt, and H. Schlesner. 1995. Unraveling the extent of diversity within the order Planctomycetales. Appl. Environ. Microbiol. 61:2270-2275.

58. Ward-Rainey, N., F. A. Rainey, H. Schlesner, and E. Stackebrandt. 1995. Assignment of hitherto unidentified 16S rDNA species to a main line of descent within the domain Bacteria. Microbiology 141:3247-3250.

59. Wayne, L. G., D. J. Brenner, R. R. Colwell, P. A. D. Grimont, O. Kandler, M. I. Krichevsky, L. H. Moore, W. E. C. Moore, R. G. E. Murray, E. Stackebrandt, M. P. Starr, and H. G. Trüper. 1987. Report of the Ad Hoc Committee on Reconciliation of Approaches to Bacterial Systematics. Int. J. Syst. Bacteriol 37:463-464.

60. Wise, M. G., J. V. McArthur, and L. J. Shimkets. 1996. Microbial diversity in a Carolina bay as determined by $16 \mathrm{~S}$ rRNA gene cloning and sequencing, abstr. N111a. In Abstracts of the 96th General Meeting of the American Society for Microbiology 1996. American Society for Microbiology, Washington, D.C

61. Woese, C. R. 1987. Bacterial evolution. Microbiol. Rev. 51:221-271.

62. Zavarzin, G. A. 1961. Budding bacteria. Microbiology (Engl. Transl. Mikrobiologiya) 30:774-791. 